\title{
STRATEGI PEMBELAJARAN AKTIF UNTUK KEMAHIRAN BERBICARA BAHASA ARAB
}

\author{
Nurlaila, M. Pd., dan Nurdiniawati, M. Pd. \\ Nurlaila.hn@yahoo.com \\ (Dosen Fakultas Tarbiyah IAI Muhammadiyah Bima)
}

\begin{abstract}
المللغصص
أصله من اللغة الإنجليزية التى تتكون من الكلمتين وعما التعليم (Active learning) التعليم العاملى بمعنى المجتهد. التعليم العاملى هو من إحدى طر:قة من طرق (active) بمعنى تهذب، والعاملى(learning) التعليم التى تشتمل على طريقة وكيفية والعملية التعليم العاملي لطلاب. هذه الطريقة يصبدر الى رأى وميل سلبرمان يعني ما سمعت ذسيت، ما سمعت وماشههدت تدكرت قليلا، ما سمعت (kofisius) كنفيز وماشهدت وما سألت وشـاورت فهمت، ما سمعت وماشهدت وما سألت وشـاورت وعملت نلت منها العلوم والمهارة، ماعملت كلمهم توليت من ذلك. المبادئ الأسـاس في تعليم العاملى هي أن يكون المدرس يعلم الطلاب عامليا لأنه يحتاج في عملية التعليم أن يجعل الطلاب ايجابيا. أن الكلام يعتبر عملية انفعالية اجتماعية، فهناك مصدر للأفكار والاتجاه الذى تأخذه والموقف الذى تقال فيه، والشخص الذى تقال لله. كلمات المفتاح: الأسلوب, التعليم العاملي, المهارات اللغة.

Siswa belajar secara aktif ketika mereka melihat secara terus menerus baik secara mental maupun fisik. Pembelajaran aktif itu penuh semangat, hidup, giat, berkesinambungan, kuat, dan efektif. Pembelajaran aktif melibatkan pembelajaran yang terjadi ketika siswa bersemangat, siap secara mental, bisa memahami pengalaman yang dialami, siaga dan membuat siswa terlibat dalam pembelajaran.Untuk menjaga agar pikiran selalu siaga, ragamkanlah langkah dan jenis kegiatan. Setiap pelajaran menyediakan ide-ide untuk merubah langkah dan setiap pelajaran disiapkan untuk bisa diadaptasikan. Merubah model kerja siswa dari kerja kelompok besar menjadi kerja indifidual atau kelompok kecil adalah salah satu cara yang mudah dan efektif untuk meragamkan langkah mental. Siswa perlu merasa bahwa mereka adalah bagian dari proses pembelajaran. Untuk memfasilitasi hal ini, setiap rencana pembelajaran menyertakan satu sesi yang disebut tujuan pembelajaran terukur, yang merangkum tujuan-tujuan pembelajaran yang kemudian dijelaskan kepada siswa dan satu sesi di akhir pelajaran yang disebut refleksi pemikiran mendalam, yang menyertakan saran untuk membantu siswa untuk mereflesikan kembali pengalaman yang mereka peroleh untuk mengukur ketercapaian tujuan dan mengetahui apakah mereka mengalami flow selama pelajaran berlangsung. Belajar aktif sangat diperlukan oleh peserta didik untuk mendapatkan hasil belajar yang maksimum. Ketika siswa hanya menerima dari guru, ada kecenderungan untuk melupakan apa yang telah diberikan. Oleh karena itu diperlukan perangkat tertentu untuk dapat mengikat informasi yang baru saja diterima dari guru.
\end{abstract}

Kata Kunci: Strategi, Pembelajaran Aktif, Kemahiran Berbicara. 


\section{A. PENDAHULUAN}

Pembelajaran aktif adalah suatu pembelajaran yang mengajak peserta didik untuk belajar secara aktif dengan menggunakan otak secara maksimal untuk menemukan ide pokok dari materi pembelajaran, memecahkan persoalan atau mengaplikasikan apa yang baru mereka pelajari ke dalam suatu persoalan yang ada dalam kehidupan nyata baik secara mental maupun fisik.

Belajar aktif sangat diperlukan oleh peserta didik untuk mendapatkan hasil belajar yang maksimum. Salah satu yang menyebabkan informasi cepat dilupakan adalah kelemahan otak manusia itu sendiri. Belajar yang hanya mengandalkan indera pendengaran mempunyai beberapa kelemahan, padahal hasil belajar seharusnya disimpan sampai waktu yang lama, sesuai dengan kata-kata mutiara yang diberikan oleh seorang filosof kenamaan dari Cina, Konfusius. Dia mengatakan: “Apa yang saya dengar, saya lupa. Apa yang saya lihat, saya ingat. Apa yang saya lakukan, saya paham".Penelitian menunjukkan bahwa memberi pertanyaan kepada peserta didik atau menyuruh mereka untuk mendiskusikan materi yang baru saja diberikan mampu meningkatkan nilai evaluasi dengan kenaikan yang signifikan. ${ }^{1}$

Salah satu alasan mengapa sebagian besar orang cenderung lupa tentang apa yang mereka dengar adalah tingkat kecepatan bicara guru dengan tingkat kecepatan pendengaran siswa. Pada umumnya guru berbicara dengan kecepatan 100 hingga 200 kata permenit sementara siswa yang benar-benar berkonsentrasi dapat mendengarkan 50 hingga 100 kata permenit. Bahkan, sebuah penelitian menunjukkan bahwa dalam perkuliahan bergaya ceramah, mahasiswa kurang menaruh perhatian selama $40 \%$ dari seluruh waktu kuliah (Pollio 1984). Mahasiswa dapat mengingat 70\% dalam sepuluh menit pertama kuliah, sedangkan sepuluh menit terakhir, mereka hanya dapat mengingat $20 \%$ materi kuliah (McKeachie, 1986). ${ }^{2}$

Untuk bisa mempelajari sesuatu dengan baik, kita perlu mendengarnya, melihatnya, mengajukan pertanyaan tentangnya dan membahasnya dengan orang lain juga mengerjakannya yakni menggambarkan sesuatu dengan cara mereka sendiri, menunjukkan contohnya, mencoba mempraktikkan keterampilan, dan mengerjakan tugas yang menuntut pengetahuan yang telah atau harus mereka dapatkan. ${ }^{3}$

\footnotetext{
${ }^{1}$ Hisyam Zaini, Dkk, Strategi Pembelajaran Aktif, (Yogyakarta: CTSD, 2007), xvi.

${ }^{2}$ Melvin L Silberman, Active Learning 101 Cara Belajar Siswa Aktif, (Bandung: Nusa Media, 2009), 24.

${ }^{3}$ Ibid., 10.
} 
Hal senada dikemukakan oleh Ekwal dan Shanker bahwa orang umumnya dapat mengingat tentang: $10 \%$ dari apa yang mereka baca, $20 \%$ dari apa yang mereka dengar, $30 \%$ dari apa yang mereka lihat, 50\% dari apa yang mereka lihat dan dengar, $70 \%$ dari apa yang mereka ucapkan dan 90\% dari apa yang mereka ucapkan dan lakukan bersamasama.

Oleh karena itu, untuk memaksimalkan belajar, buat belajar aktif, buatlah episodik. Bila memungkinkan, rancang aktifitas yang melibatkan siswa dalam kegiatan fisik selain berbicara, mendengarkan, membaca, dan melihat. Ciptakan pengalaman belajar yang benar-benar adalah pengalaman. Selain itu, buat pengalaman belajar yang dramatis, beri ia sentuhan emosional. Jill Neimark mengatakan bahwa "suatu memori yang dikaitkan dengan informasi yang dipicu secara emosional akan terpatri dalam otak". ${ }^{4}$

\section{Karakteristik Pembelajaran Aktif}

Menurut Bonwell pembelajaran aktif memiliki karakteristik sebagai berikut:

a. Penekanan proses pembelajaran bukan pada penyampaian informasi oleh pengajar melainkan pada pengembangan keterampilan pemikiran analitis dan kritis terhadap topik atau permasalahan yang dibahas.

b. Siswa tidak hanya mendengarkan pelajaran secara pasif, tetapi mengerjakan sesuatu yang berkaitan dengan materi pelajaran.

c. Penekanan pada eksplorasi nilai-nilai dan sikap-sikap berkenaan dengan materi pelajaran.

d. Siswa lebih banyak dituntut berpikir kritis, menganalisa dan melakukan evaluasi.

e. Umpan balik yang lebih cepat akan terjadi pada proses pembelajaran. ${ }^{5}$

\section{Pentingnya Pembelajaran Aktif}

Penelitian menunjukkan bahwa semakin banyak siswa terlibat dalam belajar, maka mereka lebih banyak mengerti dan mengingat pembelajaran dalam waktu yang lebih lama, karena kuncinya adalah keterlibatan. Howard Hendricks dalam bukunya "Teaching to Changes Lives" mengatakan "Pembelajaran maksimal adalah hasil dari keterlibatan maksimal" survey menunjukkan bahwa seseorang kehilangan pekerjaan bukan karena

\footnotetext{
${ }^{4}$ Paul Ginnis, Trik dan Taktik Mengajar Strategi Meningkatkan Pencapaian Pengajaran di Kelas, (Jakarta: PT Indeks, 2008), 28.

${ }^{5}$ Umi Mahmudah, Abdul Wahab Rosyidi, Active Learning dalam Pembelajaran Bahasa Arab, (Malang: UIN Malang Press, 2008), 64.
} 
pengetahuannya, akan tetapi karena ketidakmampuannya dalam bekerja sama. Tom Jackson dalam bukunya "Activities that Teach" penguasaan life Skill merupakan persyaratan dasar untuk semua. ${ }^{6}$

\section{Keuntungan Pembelajaran Aktif}

Secara umum dengan melakukan pembelajaran secara aktif akan diperoleh hal-hal sebagai berikut :

a. Interaksi yang timbul selama proses pembelajaran akan menimbulkan positive interdependence dimana konsolidasi pengetahuan yang dipelajari hanya dapat diperoleh secara bersama-sama melalui eksplorasi aktif dalam belajar.

b. Setiap individu harus terlibat aktif dalam proses pembelajaran dan pengajar harus dapat mendapatkan penilaian untuk setiap mahasiswa sehingga terdapat individual accountability.

c. Proses pembelajaran aktif ini agar berjalan dengan efektif diperlukan tingkat kerjasama yang tinggi sehingga dapat memupuk social skill.

Adapun secara lebih spesifik akan didapatkan hal-hal sebagai berikut :

a) Siswa termotivasi karena lebih mudah belajar disaat enjoy.

b) Berlangsung dalam lingkungan yang tenang, karena percobaan dan kegagalan diterima.

c) Adanya partisipasi dari semua kelompok.

d) Tiap orang bertanggung jawab atas pembelajarannya masing-masing.

e) Fleksibel dan relavan.

f) Sesuatu yang didapat menjadi bertambah.

g) Terdorongnya pemikiran induktif.

h) Semua menyatakan pemikirannya.

i) Masing-masing memberikan koreksi jika ada kesalahan

j) Memberikan resiko lebih besar. ${ }^{7}$

\section{Alasan Penggunaan Pembelajaran Aktif}

Dalam bukunya "Cooperative Learning" Spencer Kagan menyatakan, pembelajaran aktif menjadikan para siswa menggunakan talentanya masing-masing dalam proses

${ }^{6}$ Ibid., 71.

${ }^{7}$ Ibid., 72. 
belajar, terlebih dengan mengkobinasikannya, tidak condong pada satu kelompok saja. Hal itu terlihat sebagai berikut:

a. Siswa visual menampilkan yang terbaik ketika mereka mendapatkan sesuatu dari informasi baru yang kemudian dipresentasikannya.

b. Siswa auditori, menerima informasi melalui kata-kata yang diucapkan

c. Siswa kinestetik, belajar dengan menggunakan gerakan. ${ }^{8}$

\section{Proses Pembelajaran Aktif}

a. Konsep umum dipresentasikan pada kelompok.

b. Informasi khusus tentang konsep diterima oleh kelompok.

c. Aktifitas dilakukan oleh kelompok.

d. Kelompok mengerahkan dan konsekuensi selama aktifitas.

e. Diskusi kelompok dilaksanakan lansung diikuti kesimpulan dari aktiftas.

f. Prinsip umum diskusi.

g. Aplikasi kehidupan spesifik berasal dari dasar atau prinsip-prinsip umum.

h. Aplikasi kehidupan diinternalisasi oleh tiap individu berdasakan kebutuhan dan kesiapan.

i. Perwakilan-perwakilan bertindak berdasarkan atas apa yang telah dipelajari. ${ }^{9}$

\section{Strategi Pembelajaran Kalâm}

Berbicara dengan bahasa asing merupakan keterampilan dasar yang menjadi tujuan dari beberapa tujuan pengajaran bahasa. Sebagaimana bicara adalah sebagai sarana untuk berkomunikasi dengan orang lain. Kegiatan berbicara di dalam kelas bahasa mempunyai aspek komunikasi dua arah, yaitu antara pembicara dan pendengarnya secara timbal balik. Dengan demikian latihan berbicara harus terlebih terdahulu didasari oleh kemampuan mendengarkan, kemampuan mengucapkan dan penguasaan kosa kata juga ungkapan yang memungkinkan siswa dapat mengkomunikasikan maksud/fikirannya.

Latihan berbicara merupakan kelanjutan dari latihan menyimak yang di dalam kegiatannya juga terdapat latihan mengucapkan. Kunci keberhasilan dari latihan berbicara adalah tergantung pada kreatifitas guru dalam memilih topik/materi yang sesuai dengan kemampuan siswa. Faktor lain dalam menghidupkan kegiatan berbicara adalah keberanian siswa dan perasaan tidak takut salah. Oleh karena itu guru harus dapat

${ }^{8}$ Ibid., 73 .

${ }^{9}$ Ibid., 75 . 
memberikan dorongan kepada siswa agar berani berbicara kendatipun demgan resiko salah. ${ }^{10}$

Adapun langkah-langkah yang bisa dilakukan guru dalam proses pembelajaran kalâm adalah sebagai berikut:

a. Bagi Pembelajar Mubtadi' (pemula)

1. Guru mulai melatih bicara dengan memberi pertanyaan-pertanyaan yang harus dijawab oleh siswa.

2. Pada saat yang bersamaan siswa diminta untuk belajar mengucapkan kata, menyususn kalimat, dan mengungkapkan pikiran.

3. Guru mengurutkan pertanyaan-pertanyaan yang dijawab oleh siswa sehingga berakhir membentuk sebuah tema yang sempurna.

4. Guru bisa menyuruh siswa menjawab latihan-latihan syafawiyah, menghafal percakapan atau menjawab pertanyaan yang berhubungan dengan isi teks yangbtelah siswa baca.

b. Bagi pembelajar mutawasith (lanjutan)

1. Belajar berbicara dengan bermain peran.

2. Berdiskusi dengan tema tertentu

3. Bercerita tentang peristiwa yang terjadi pada siswa.

4. Bercerita tentang informasi yang telah didengar dari televisi, radio, atau lainnya.

c. Bagi pembelajar mutaqaddim (tingkat atas)

1. Guru memilihkan tema untuk berlatih kalam.

2. Tema yang dipilih hendaknya menarik berhubungan dengan kehidupan siswa.

3. Tema harus jelas dan terbatas.

4. Mempersilahkan siswa memilih dua tema atau lebih sampai akhirnya siswa bebas memilih tema yang dibicarakan tentang apa yang mereka ketahui.

Beberapa petunjuk umum berkenaan dengan pembelajaran kalâm, yaitu sebagai berikut:

1) Belajar kalam yakni berlatih berbicara.

2) Hendaknya siswa mengungkapkan tentang pengalaman mereka.

3) Melatih memusatkan perhatian .

4) Tidak memutus percakapan dan sering membenarkan.

\footnotetext{
${ }^{10}$ Ahmad Fuad Effendy, Metodologi Pengajaran Bahasa Arab, (Malang: Misykat, 2008), 110.
} 
5) Bertahap.

6) Kebermaknaan tema, siswa akan lebih termotifasi untuk berbicara jika temanya berhubungan dengan hal yang bernilai dalam kehidupan mereka. ${ }^{11}$

\section{B. Strategi Pembelajaran Aktif Untuk Kemahiran Berbicara Bahasa Arab}

Dalam pembelajaran aktif untuk kemahiran berbicara bahasa Arab ada beberapa langkah yang harus dilakukan dalam kegiatan pembelajaran sebagai berikut;

\section{Delegasi}

Pembelajaran bahasa Arab dengan menggunakan strategi delegasi ada beberapa teknik yang perlu dilakukan dalam kegiatan pembelajaran bahasa arab. antara lain;

1) Buat stasium sumber (resource station) di sekeliling ruang. Ini bisa mencakup gabungan poster untuk dikaji, percobaan untuk dilaksanakan, video pendek untuk ditonton, dalam buku teks untuk dibaca, kaset audio untuk didengarkan (menggunakan listening centre dan banyak heandphone), presentasi powerpoint untuk dilihat di PC, situs internet untuk dikunjungi.

2) Siswa membentuk kelompok rumah, yang terdiri dari, misalnya, lima orang. Tiap kelompok memiliki tujuan yang sama, untuk memahami dan mempelajari semua aspek dari topik yang dipamerkan disekeliling ruang.

3) Maka, tiap kelompok menentukan siapa yang dikirim ke lokasi sumber, bisa dengan mempertimbangkan style belajar yang disukainya. Utusan ini kemudian pergi kelokasi sumber mereka dan bekerja sesuai dengan deadline waktu yang sama untuk memahami materi dan dan membuat catatan untuk dibawa kembali ke kelompoknya. Delegasi dari kelompok yang berbeda dapat saling membantu untuk menguasai materi sehingga tiap orang kembali ke kelompok sendiri dengan merasa jelas dan percaya diri.

4) Saat kembali, kelompok mereka bergantian untuk saling mengajari. Guru berkeliling memantau kualitas pengajaran dan menjawab pertanyaan untuk klarifikasi. $^{12}$

\footnotetext{
${ }^{11}$ Abdul Hamid,dkk, Pembelajaran Bahasa Arab (Pendekatan, Metode, Strategi, Materi dan Media), (Malang: UIN-Malang Press, 2008), 42-43.

${ }^{12}$ Ginnis, Trik dan Taktik 107.
} 


\section{Bisnis Berisiko}

Pembelajaran bahasa Arab dengan menggunakan strategi bisnis berisiko ada beberapa langkah atau teknik yang dilakukan oleh guru. Seperti berikut ini;

a. Siapkan satu set pertanyaan yang harus dijawab siswa. Pertanyaan ini sebaiknya disusun dalam urutan logis, diberi huruf A, B, C, D... di belakang, dan dibuat menjadi pak kartu secukupnya sehingga satu pak untuk tiap kelompok.

b. Siswa belajar dalam kelompok berenam. Tiap kelompok duduk di meja dengan pak kartunya ditengah meja, muka dibawah, dengan kartu A di atas. Mereka juga punya dadu. Tiap orang memilki nomor, 1-6.

c. Kelompok menentukan siapa mulai dahulu. Pemain pertama melempar dadu dan orang dengan nomor yang ditujukan dadu mengambil kartu pertama dan merespons prompt atau pertanyaannya.

d. Pemain kedua melempar dadu. Orang dengan angka yang keluar mengambil kartu B dan memberi respons... dan terus berkeliling sampai kartunya habis. Karena pertanyaannya berkaitan, dan karena tidak seorangpun tahu nomor siapa berikutnya, semua harus terus memperhatikan. ${ }^{13}$

\section{Komidi Putar Diskusi}

Pembelajaran bahasa Arab dengan menggunakan komidi putar diskusi guru dituntut untuk menggunakan teknik atau langkah-langkah berikut ini;

a. Tiap orang menghadap seorang rekan.

b. Pasangan yang berhadapan diberipertanyaan dan membuat percakapan selama sekitar tiga menit. Mereka diminta untuk memastikan bahwa masing-masing berkesempatan untuk berbicara. Guru memberitahu jika waktuntya tinggal setengah.

c. Saat waktu habis, lingkaran luar berdiri dan berputar (lebih tepatnya mengacak berkeliling) kekiri sampai guru meminta berhenti, dan menghadap rekan acak yang baru.

d. Sebelum pasangan baru ini memulai percakapan mereka, untuk lebih lanjut membicarakan subjek, masing-masing harus meringkas kontribusi rekan sebelumnya kepada lainnya. Kecakapan mendengarkan didahulukan.

\footnotetext{
${ }^{13}$ Ibid., 109.
} 
e. Sekali lagi, saat waktu habis, lingkaran luar "berputar" dan pasangan baru terbentuk. Siswa harus meringkas kontribusi rekan pertama dan keduanya sebelum melakukan percakapan ketiga mereka.

f. Kegiatan bisa diulang sebanyak diperlukan.

\section{Forum Theatre}

Forum theatre pembelajaran bahasa Arab yang sangat tepat digunakan dalam pembelajaran bahasa Arab untuk kemahiran kalam. Dengan demikian, ada beberapa teknik yang perlu dilakukan oleh guru jika menggunakan strategi tersebut antara lain;

a. Idealnya kelompok duduk dalam lingkaran

b. Perkenalkan situasi yang akan digambarkan. Situasi ini sebaiknya melibatkan sedikit pemain. Situasi ini akan memerlukan semacam ketegangan

c. Tentukan dimana peristiwa itu terjadi,kapandan apa kalimat pembukanya

d. Minta siswa untuk sukarela mengambil peran. Sukarelawan menata perabot dan mainkan adegan secara spontan selama tiga atau empat menit.

e. Begitu adegan berjalan baik, penonton bebas untuk menghentikan aksi dengan mengangkat tangan. Mereka melakukan hal ini untuk memberi saran modifikasi. Misalnya, seseorang meminta sang ayah lebih keras, atau sang anak lelaki menangis atau sang ibu menggunakan kesempatan ini untuk mengatakan bagaimana dia selalu benci disuruh bergegas-gegas oleh suaminya. Sebagai tambahan, penonton dapat minta mengambil alih salah satu peran, atau bergabung dengan pemain asli dan menghasilkan suatu "karakter gabungan". Demikian juga, pemain dapat menghentikan aksinya dan minta saran dari penonton, atau dapat minta seseorang mengambil alih jika mereka telah cukup.

f. Seperti bagian dari video, aksi ini dapat diputar ulang dan bagiannya dimainkan ulang dengan cara yang berbeda dengan kepercayaan diri yang lebih pada sang anak lelaki, misalnya. Dengan penanda yang sama, aksi ini dapat diputar kemomen yang baru dan menarik dimasa depan. Ini membuat konsekuensi dan efeknya diamati. Drama ini selalu dapat diambil lagi dan arah kegiatan yang baru dapat dijelajahi.

g. Semua ini membuat drama tersebut dapat dibentuk. Hal ini memungkinkan kelompok memahami efek dari sikap, bahasa, dan perilaku yang berbeda, dan konsekuensi dari aksi yang berbeda. 
h. Tujuan belajar utama dapat dibawa dalam tanya jawab. Guru tidak harus menunggu sampai selesai. Dia dapat menghentikan kegiatan itu kapanpun dan memimpin diskusi atau memberi masukan. ${ }^{14}$

\section{Tebak Siapa}

Strategi tebak siapa memiliki prosedur yang berbeda dengan strategi-strategi tersebut di atas meskipun sama-sama untuk pembelajaran kemahiran berbicara bahasa Arab. Adapun teknik yang dilakukan adalah:

a. Siswa bekerja dalam kelompok berempat, duduk sedemikian rupa sehingga anggotanya dapat dengan mudah saling melihat dan mendengar.

b. Beri tiap kelompok satu pak kartu, yang dikocok dan diletakkan terbalik di tengah meja. Kartu tersebut menggambarkan benda-benda yang harus dia pelajari.

c. Anggota kelompok sepakat untuk bergiliran atau memiliki angka dan menggunakan dadu untuk menentukkan giliran. Pemain yang mendapat giliran mengambil kartu paling atas dan melihatnya, menjaganya agar tidak dilihat lainnya.

d. Anggota lainnya bertanya. Pemain yang memegang "ya" atau "tidak". Jika perlu, jumlah pertanyaan atau waktu dapat dibatasi.

e. Begitu benda tersebut telah berhasil dikenali oleh kelompok tersebut, giliran untuk pemain berikutnya. ${ }^{15}$

\section{Berburu Informasi}

Strategi berburu informasi digunakan dalam pembelajaran kemahiran kalâm agar siswa berperan aktif untuk mencari dan mendapatkan informasi sehingga pembelajaran berjalan sesuai dengan yang direncanakan. Supaya strategi ini berjalan dengan baik, guru perlu melakukan langkah-langkah berikut;

a. Siswa ditugaskan untuk mencari informasi tentang topik yang sedang dibahas. Tiap siswa disediakan lembar Pencari Fakta.

b. Untuk siswa remaja kegiatan ini bisa dalam bentuk peta pemburu yang memberi lokasi didalam ruang kelas semakin jauh tempatnya semakin baik dimana jenisjenis materi dapat ditemukan.

c. Pada titik manapun dalam kegiatan, siswa dapat mendatangi guru untuk mengecek bagaimana mereka bekerja.

${ }^{14}$ Ibid., 121.

${ }^{15}$ Ibid., 126. 
d. Segera setelah seseorang memiliki satu set jawaban lengkap/ telah membuka kotak harta/ punya full house, atau segera setalah waktu habis, aktivitas dihentikan dan guru membahas pertanyaan bersama-sama. ${ }^{16}$

\section{Jigsaw}

Jigsaw merupakan model pembelajaran koorperatif (coorperative learning) agar siswa berperan aktif dalam satu tim atau kelompok. Model pembelajaran ini dapat dilakukan teknik-teknik seperti di bawah ini;

a. Pilihlah materi pelajaran/kuliah yang dapat dibagi menjadi beberapa segmen (bagian).

b. Bagi siswa/mahasiswa menjadi beberapa kelompok sesuai dengan jumlah segmen yang ada.

c. Setiap kelompok mendapat tugas membaca dan memahami materi kuliah yang berbeda-beda.

d. Setiap kelompok mengirimkan anggotanya kekelompok lain untuk menyampaikan apa yang telah mereka pelajari dikelompok.

e. Kembalikan suasana kelas seperti semula kemudian tanyakan sekiranya ada persoalan-persoalan yang tidak terpecahkan dalam kelompok.

f. Beri siswa/mahasiswa beberapa pertanyaan untuk mengecek pemahaman mereka terhadap materi. ${ }^{17}$

\section{Peer Lessons}

Peer lesson adalah sebuah strategi pembelajaran yang mengembangkan Peer Teaching dalam kelas yang menempatkan seluruh tanggung jawab untuk mengajar pada peserta didik sebagai anggota kelas. Pembelajaran dengan menggunakan strategi ini guru melakukan langkah-langkah berikut;

a. Bagi siswa/mahasiswa menjadi kelompok-kelompok kecil sebanyak segmen materi yang akan anda sampaikan.

b. Masing-masing kelompok kecil diberi tugas untuk mempelajari satu topik materi, kemudian mengajarkannya kepada kelompok lain. Topik-topik yang diberikan harus yang saling berhubungan

\footnotetext{
${ }^{16}$ Ibid., 136.
}

${ }^{17}$ Hisyam, Strategi Pembelajaran 59. 
c. Minta setiap kelompok menyiapkan strategi untuk menyampaikan materi kepada teman-teman sekelas. Sarankan kepada mereka untuk tidak menggunakan metode ceramah atau seperti membaca laporan.

d. Buat beberapa saran seperti; Menggunakan alat bantu visual,Menyiapkan media pengajaran yang diperlukan,Menggunakan contoh-contoh yang relevan,Melibatkan siswa/mahasiswa (kawan) dalam proses pembelajaran melalui diskusi, permainan, quiz, studi kasus,Memberi kesempatan kepada yang lain untuk bertanya.

e. Beri mereka waktu yang cukup untuk persiapan, baik didalam maupun diluar kelas

f. Setiap kelompok menyampaikan materi sesuai tugas yang telah diberikan.

g. Setelah semua kelompok melaksanakan tugas, beri kesimpulan dan klarifikasi sekiranya ada yang perlu diluruskan dari pemahaman siswa/mahasiswa. ${ }^{18}$

\section{Benar-benar Mengenal}

Pembelajaran bahasa Arab dengan strategi benar-benar mengenal memiliki kemiripan dengan dengan strategi peer lessons dengan mengkondisikan siswa agar berperan aktif dalam pembelajaran khususnya ketrampilan berbicara. agar strategi ini berjalan dengan baik hendaknya guru menggunakan teknik-teknik berikut;

a. Pasangkan siswa dengan cara yang anda kehendaki. Kriteria untuk memasangkan siswa bisa mencakup:Dua siswa yang belum pernah bertemu sebelumnya, Dua siswa yang tidak pernah bekerja bersama, Dua siswa yang berasal dari jurusan atau latar belakang yang berbeda,Dua siswa yang memiliki tingkat pengetahuan atau pengalamanyang berbeda.

b. Perintahkan pasangan-pasangan yang sudah terbentuk untuk saling berkenalan dan mengakrabkan diri selama 30 hingga 60 menit. Sarankan agar mereka berjalanjalan bersama, minum kopi atau jika mungkin untuk saling mengunjungi.

c. Berikan beberapa pertanyaan yang bisa digunakan oleh siswa untuk saling mewawancarai.

d. Bila seluruh siswa sudah kembali berkumpul, berikan pasangan-pasangan itu tugas untuk dikerjakan bersama yang memungkinkan mereka untuk mulai mempelajari materi pelajaran.

e. Pertimbangkan kecocokan pasangan untuk kemudian dibentuk menjadi kemitraan belajar jangka panjang. ${ }^{19}$

${ }^{18}$ Ibid., 65. 


\section{Mengabarkan Kembali}

Salah satu strategi yang digunakan dalam pembelajaran kemahiran kalâm adalah mengabarkan kembali. Maksudnya adalah proses pembelajaran yang interaktif dengan cara guru mengajukan pertanyaan kemudian dijawab kembali oleh siswa. Agar lebih jelasnya perhatikanlah langkah-langkah berikut ini;

a. Sambut kembali kedatangan siswa kedalam kelas. Jelaskan apa yang menurut anda berharga untuk meluangkan beberapa menit guna mengakrabkan kembali sebelum memulai pelajaran hari ini.

b. Ajukan satu atau beberapa pertanyaan berikut ini kepada siswa: Apa yang kalian ingat tentang pelajaran kita yang lalu? Apa yang menarik menurut kalian?, Pernahkah kalian membaca/memikirkan/mengerjakan sesuatu yang distimulasi oleh pelajaran kita yang lalu?,Pengalaman menarik apakah yang kalian dapatkan selama mengikuti mata pelajaran ini?, Apa yang ada dipikiran kalian sekarang Bagaimana perasaan kalian hari ini?, Buatlah pertanyaan anda sendiri. ${ }^{20}$

\section{Pertanyaan Penilaian}

Strategi yang baik adalah strategi yang bisa diterapkan, sesuai dengan tingkat pemahaman siswa serta materi pembelajaran. Strategi pertanyaan penilaian adalah salah strategi pembelajaran kemahiran kalam. Agar pembelajaran berjalan dengan baik sesuai dengan yang harapkan agar diperhatikan langkah-langkah berikut;

a. Susunlah tiga atau empat pertanyaan untuk mempelajari seperti apa siswa anda. Anda dapat menyertakan pertanyaan-pertanyaan tentang hal-hal berikut ini:Pengetahuanmereka tentang materi pelajaran, Sikap mereka terhadap materi pelajaran, Pengalaman-pengalaman siswa yang relevan dengan materi pelajaran, Keterampilan yang telah mereka dapatkan, Latarbelakang mereka,Apa yang mereka butuhkan atau harapkan dari mata pelajaran ini.

b. Bagilah siswa yang menjadi kelompok tiga orang (trio) atau empat orang (kuartet) [tergantung jumlah pertanyaan yang telah anda buat]. Beri setiap siswa satu dari masing-masing pertanyaan penilaian. Mintalah dia untuk mewawancarai siswa lain dalam kelompok dan dapatkan (serta catat) jawaban atas pertanyaan yang diberikan kepadanya.

${ }^{19}$ Silberman, Active Learning 78 .

${ }^{20}$ Ibid., 82. 
c. Kumpulkan kembali siswa dalam sub-sub kelompok yang telah diberi pertanyaan yang sama.

d. Perintahkan tiap sub kelompok untuk menyatukan data mereka dan mengikhtisarkannya. Kemudian perintahkan tiap sub kelompok untuk melaporkan kepada seluruh siswa apa yang telah mereka pelajari satu sama lain. ${ }^{21}$

\section{Bertukar Pendapat}

Bertukar pendapat sama dengan strategi diskusi kelompok dengan tujuan agar siswa saling mengenal dan menukar informasi tentang sesuatu. pembelajaran dengan strategi ini akan berjalan dengan baik jika guru memperhatikan tekni-teknik berikut ini;

a. Berikan label nama kepada tiap siswa. Perintahkan siswa untuk menuliskan nama mereka pada label dan mengenakannya

b. Perintahkan siswa untuk berpasangan dan memperkenalkan diri kepada siswa lain. Kemudian perintahkan pasangan-pasangan tersebut untuk berbagi pendapat tentang jawaban atas pertanyaan atau pernyataan provokatif yang memancing opini mereka tentang persoalan seputar materi yang anda ajarkan.

c. Ucapkan "kerjakan sekarang", dan arahkan siswa untuk bertukar label nama atau tanda pengenal mereka dengan pasangannya dan kemudian menemui siswa lain. Perintahkan siswa, bukannya untuk memperkenalkan diri, melainkan berbagi pendapat dari siswa yang merupakan pasangan sebelumnya (yakni siswa yang label/tanda pengenalnya ia kenakan sekarang)

d. Selanjutnya, perintahkan siswa untuk berganti label nama lagi dan mencari siswa lain untuk diajak bicara, dan berbagi pendapat dari siswa yang tanda pengenalnya ia kenakan sekarang

e. Lanjutkan proses itu hingga sebagian besar siswa telah saling bertemu. Kemudian katakan kepada tiap siswa untuk mendapatkan kembali label namanya sendiri. ${ }^{22}$

\section{Benar atau Salah}

Khata' (salah) dan sahih (benar) denga memberikan beberapa buah pernyataan yang agak mirip atau berbeda. Perhatikan langkah-langkah berikut;

a. Susunlah sebuah daftar pernyataan yang terkait dengan materi pelajaran anda, yang setengahnya benar dan setengahnya salah. Sebagai contoh, pernyataan

${ }^{21}$ Ibid., 89.

${ }^{22}$ Ibid., 109. 
"Mariyuana bisa menimbukan kecanduan" adalah benar, dan pernyataan "Alkohol merupakan obat perangsang" adalah salah. Tulis tiap pernyataan pada kartu indeks yang terpisah. Pastikan jumlah kartunya sesuai dengan jumlah siswa yang hadir. (jika siswa yang hadir jumlahnya ganjil, pilihlah satu kartu untuk anda sendiri).

b. Bagikan satu kartu untuk satu siswa. Katakan kepada siswa bahwa misi mereka adalah menentukan kartu mana yang benar (berisi pernyataan benar) dan mana yang salah. Jelaskan bahwa mereka bebas memilih cara apapun yang mereka inginkan dalam menyelesaikan tugas ini.

c. Bila para siswa sudah selesai, perintahkan agar setiap kartu dibaca dan mintakan pendapat siswa tentang benar atau salahkah pernyataan tersebut. Beri kesempatan munculnya pendapat minoritas!

d. Berikan umpan balik tentang masing-masing kartu dan catat cara-cara siswa dalam bekerjasama menyelesaikan tugas ini

e. Tunjukkan bahwa dalam pelajaran ini diperlukan keterampilan tim yang positif karena hal ini menunjukkan kegiatan belajar yang sifatnya aktif. ${ }^{23}$

\section{Menemui Pembicara Tamu}

Pembelajaran kemahiran kalâm dengan strategi ini memerlukan kemampuan tenaga dan pikiran serta jumlah perbendaharaan kosakata yang banyak agar kegiatan belajar mengajar bisa belajar dengan baik. Sebaiknya guru memerhatikan hal-hal berikut ini;

a. Undanglah pembicara tamu untuk memberi ceramah kepada siswa anda sebagai pakar dalam pelajaran yang kini anda ajarkan.

b. Siapkan pembicara tamu dengan menjelaskan kepadanya bahwa sesi kelas ini akan dilaksanakan layaknya konferensi pers. Agar sesuai dengan format tersebut, pembicara mesti menyiapkan ceramah singkat atau pernyataan pembuka dan kemudian bersiap menerima pertanyaan dari "pers"

c. Sebelum hadirnya pembicara tamu, persiapkan siswa dengan mendiskusikan bagaimana konferensi pers akan dilaksanakan, dan kemudian berilah mereka kesempatan untuk merumuskan beberapa pertanyaan untuk diajukan kepada pembicara. $^{24}$

${ }^{23}$ Ibid., 111.

${ }^{24}$ Ibid., 132. 


\section{Memberikan Pertanyaan dan Mendapatkan Jawaban}

Strategi ini sangat baik untuk pembelajaran bahasa Arab untuk kemahiran kalâm sebab siswa dengan siswa maupun guru dengan siswa terjalin komunikasi dengan baik dalam kegiatan belajar. Agar stategi ini berjalan efektif guru disarankan memerhatikan hal-hal berikut;

a. Berikan dua kartu indeks kepada masing-masing siswa

b. Perintahkan tiap siswa untuk melengkapi kalimat berikut ini

Kartu 1: Saya masih memiliki pertanyaan tentang ...

Kartu 2: Saya bisa menjawab pertanyaan tentang ...

c. Buatlah sub-sub kelompok dan perintahkan tiap kelompok untuk memilih "pertanyaan paling relevan untuk diajukan" "dan pertanyaan paling menarik untuk dijawab" dari kartu anggota kelompok mereka

d. Perintahkan tiap sub kelompok untuk melaporkan "pertanyaan untuk diajukan" yang ia pilih. Pastikan apakah ada siswa yang dapat menjawab pertanyaan itu, jika tidak, guru harus menjawabnya.

e. Pertintahkan tiap kelompok untuk melaporkan "pertanyaan untuk dijawab" yang ia pilih. Perintahkan anggota sub-sub kelompok untuk berbagi jawaban dengan siswa yang lain. $^{25}$

\section{Bola Pertanyaan}

Dalam menerapakan strategi ini guru memberi setiap orang selembar kertas kosong. Mintalah setap orang menuliskan pertanyaan pada kertas itu. Minta mereka menulis dengan huruf cetak, tanpa perlu menuliskan nama, sehingga orang lain mudah membacanya. Ajaklah mereka meremas kertas itu menjad bola. Selanjutkan kumpulkan bola pertanyaan dan melemparkan bola-bola tersebut satu demi satu kepada setiap orang di dalam kelas atau meminta siswa untuk bermain perangperangan dengan saling melempar bola-bola tersebut dalam waktu 30 detik kemudian mintalah setiiap siswa untuk membuka pertanyaan dan memberikan jawaban. Fasilitator dan siswa lainnya dapat memberikan komentar bila perlu. ${ }^{26}$

\section{Tukar Tanya Antar Tim}

Dalam menerapkan strategi ini guru membagi siswa menjadi dua tim atau lebih. Mintalah setiap tim menyusun kuis yang berisi 10-20 pertanyaan untuk tim lain

\footnotetext{
${ }^{25}$ Ibid., 254.
}

${ }^{26}$ Dave Meler, The Accelarated Learning, (Bandung: Kaifa, 2002), 203. 
yang akan menguji pemahaman mereka mengenai materi pelajaran, selanjutnya timtim tersebut bertukar rangkaian pertanyaan. Tim pertama yang berhasil menjawab semua pertanyaan dengan benar akan mendapatkan hadiah. ${ }^{27}$

Seluruh strategi yang telah penulis jelaskan di atas akan berjalan dengan baik dalam proses penerapannya jika didukung oleh kemampuan guru dalam menerapkannya atau media pendukung lainnya. Sebab strategi tidak berfungsi kalau tidak didukung oleh media atau teknik-teknik yang baik. artinya guru memiliki peran dominan berjalan atau tidaknya strategi tersebut.

\section{PENUTUP}

Dari pemaparan tersebut dapat disimpulkan Pertama; Pembelajaran aktif sangat dibutuhkan dalam proses pengajaran karena dengan demikian siswa akan merasa enjoy dan termotifasi untuk belajar dengan ragam yang berfariasi. Kedua; Keterlibatan siswa dalam belajar akan lebih banyak mengerti dan mengingat pembelajaran dalam waktu yang lebih lama. Ketiga; Kegiatan berbicara bahasa Arab mempunyai aspek komunikasi dua arah secara timbal balik. Dengan demikian latihan berbicara harus terlebih terdahulu didasari oleh kemampuan mendengarkan, kemampuan mengucapkan dan penguasaan kosa kata juga ungkapan yang memungkinkan siswa dapat mengkomunikasikan maksud/fikirannya. Keempat; Kemampuan berbicara bahasa Arab siswa adalah tergantung pada kreatifitas guru dalam memilih topik/materi yang sesuai dengan kemampuan siswa. Faktor lain dalam menghidupkan kegiatan berbicara adalah keberanian siswa dan perasaan tidak takut salah. Oleh karena itu, guru harus dapat memberikan dorongan kepada siswa agar berani berbicara kendatipun dengan resiko salah. Kelima; Strategi pembelajaran aktif untuk kemahiran berbicara bahasa Arab antara lain; Delegasi, bisnis beresiko, komidi putar diskusi, forum theatre, tebak Siapa, Berburu Informasi, Jigsaw, Peer Lessons, benar-benar mengenal, mengabarkan kembali, pertanyaan penilaian, bertukar pendapat, benar atau salah, menemui pembicara tamu, memberikan pertanyaan dan mendapatkan jawaban, bola pertanyaan, tukar tanya antar Tim.

${ }^{27}$ Ibid., 204. 


\section{DAFTAR PUSTAKA}

Ahmad Fuad Effendy, Metodologi Pengajaran Bahasa Arab, Malang: Misykat, 2008.

Paul Ginnis, Trik dan Taktik Mengajar Strategi Meningkatkan Pencapaian Pengajaran di Kelas, Jakarta: PT Indeks, 2008.

Abdul Hamid, dkk, Pembelajaran Bahasa Arab Pendekatan, Metode, Strategi, Materi dan Media, Malang: UIN-Malang Press, 2008.

Umi Mahmudah, Abdul Wahab Rosyidi, Active Learning dalam Pembelajaran Bahasa Arab, Malang: UIN Malang Press, 2008.

Dave Meler, The Accelarated Learning, Bandung: Kaifa, 2002.

Melvin L. Silberman, Active Learning 101 Cara Belajar Siswa Aktif, Bandung: Nusa Media, 2009.

Hisyam Zaini, Dkk, Strategi Pembelajaran Aktif, Yogyakarta: CTSD, 2007. 